\title{
Els "Vespres científics" de l'Escola Pia
}

Marta Segura i Josep M. Valls

Escola Pia de Nostra Senyora, Barcelona

Des de fa vuit anys, pares, alumnes, ex-alumnes $i$ professors ens trobem alguns dies al vespre per fer ciència a l'abast de tothom. A més de gaudir de la ciència, aquesta activitat ens ha permès conèixer persones molt diverses, compartir experiències amb les famílies $i$ amb altres docents, i també continuar veient ex-alumnes.

\section{Objectiu}

L'objectiu principal d'aquesta activitat és apropar els diferents aspectes de la ciència a tots els públics. I fer-ho a partir de l'escola i amb els recursos propis de la mateixa escola.

Vol ser una divulgació científica de qualitat, portada al mateix nivell que els grans museus científics europeus, però realitzada en el context d'una escola.

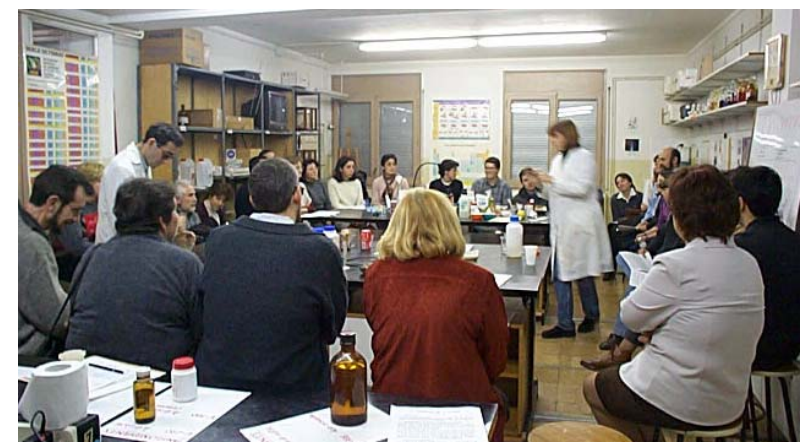

\section{Temes que tractem}

Els Vespres Científics intenten obrir una via de reflexió a tots els seus participants en cadascun dels temes que s'hi ofereixen.

En els Vespres Científics volem saber per què les coses són com són. Volem preguntar-nos el per què del nostre món, i donar respostes coherents a moltes de les coses que observem a la vida quotidiana. I això, per a tots els nivells i totes les edats.

Per això toquem temes que puguin resultar interessants per a tothom i que permetin generar interrogants i comprovacions experimentals a l'abast del públic assistent. Així, enguany hem previst els següents:
- $\quad$ Aire i buit

La pressió atmosfèrica. Tota classe d'experiències en el buit fetes amb la màquina pneumàtica. Experiències interactives amb corrents d'aire. Experiment de Torricelli. Efecte Venturi.

- Sòlids que flueixen

Experiències amb líquids especials anomenats "no newtonians". Gels, pastes, "bande blue". Fluïdesa de líquids segons la pressió exterior. Física i química d'aquestes mescles.

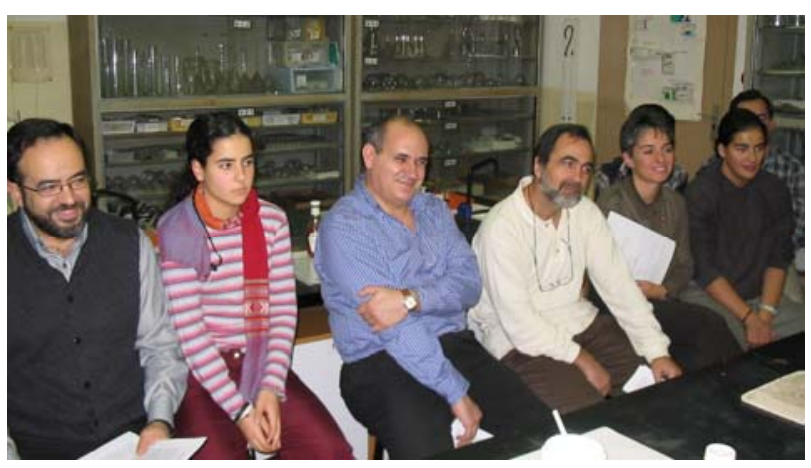

- Interior de la matèria transparent

Experiències amb llum polaritzada que permeten veure com és la matèria transparent segons l'ordre de les seves molècules. Des dels minerals i roques fins als plàstics i vidres a través d'una simfonia de colors. 


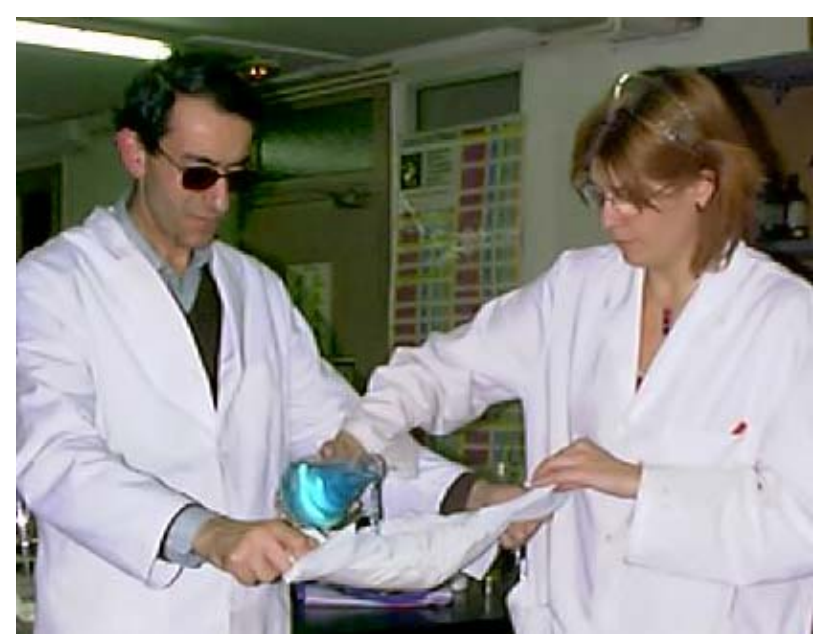

- Molt baixes temperatures

Les experiències més espectaculars amb nitrogen líquid a 200 graus sota zero: Congelació extraordinària, canvis de propietats, oxigen líquid, superconductors i levitació magnètica, nitrogen sòlid a $-211^{\circ} \mathrm{C} .$.

\section{- Química màgica}

Experiències de química presentades en forma de trucs de màgia, amb les corresponents i rigoroses explicacions a partir de reaccions químiques senzilles i no tan senzilles...

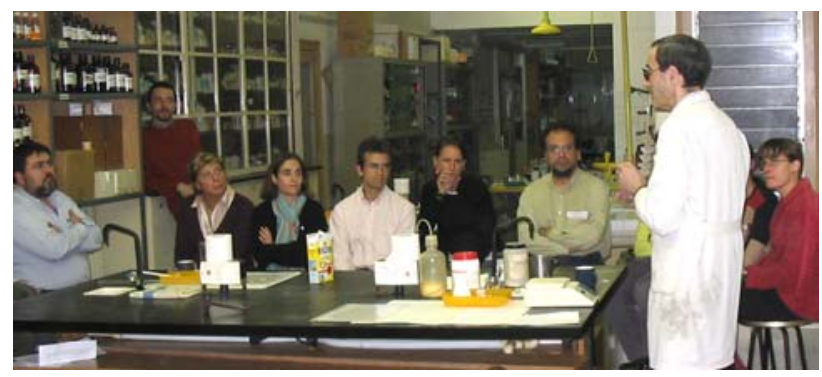

- Macro i micro: observem les cèl·lules

Introducció a l'observació de cèl.lules. Diferents tipus de cèl.lules observades al microscopi. Cèl.lules que formen els animals $i$ els vegetals.

\section{- Els perfums}

La teoria de l'olor, classes d'olors i com actua el sentit de l'olfacte. Síntesi i destil|lació d'un oli essencial (essència) i elaboració d'un perfum a partir d'olis essencials.

- Davant i darrera de l'endoll

Introducció divertida i segura a l'electricitat. Estudi de les fonts d'energia elèctrica. Realització de

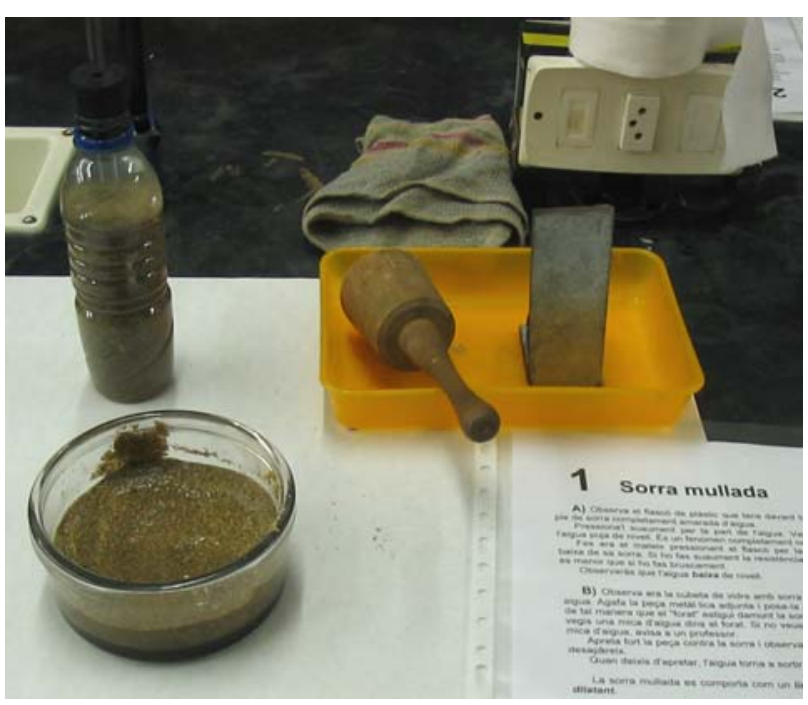

circuits elèctrics simulant circuits de la vida quotidiana.

- Física i química dels cinc sentits

Mira, escolta, olora, tasta i toca. Interpretació científica a nivell de tothom de les sensacions. Tot allò que ens permet entrar en contacte amb el món que ens envolta.

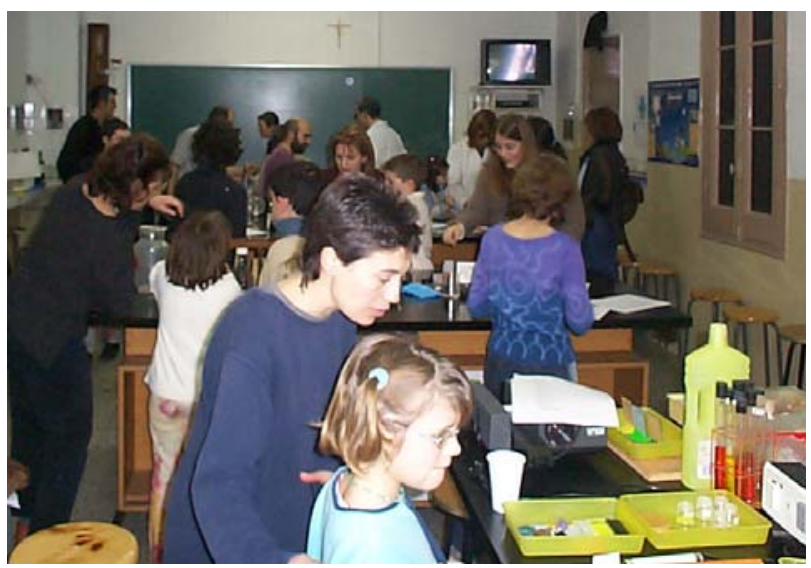

\section{Desenvolupament}

L'activitat s'organitza en tres parts. De 20'30 fins a 21'00 es projecta un vídeo divulgatiu sobre el tema que es tractarà durant el vespre. De $21^{\prime} 00$ a 21'30 els participants poden sopar. Inicialment el sopar l'organitzava l'Escola mitjançant una empresa, però amb el canvi de l'euro i la pujada de preus actualment no es fa. Els participants de l'activitat es porten un sopar fred i se'l mengen a l'Escola. Aquest moment és un dels més entranyables dels vespres, ja que la gent es pot conèixer i els que ja ens coneixem de tots aquests anys compartim una estona distesa parlant de res i de tot. 


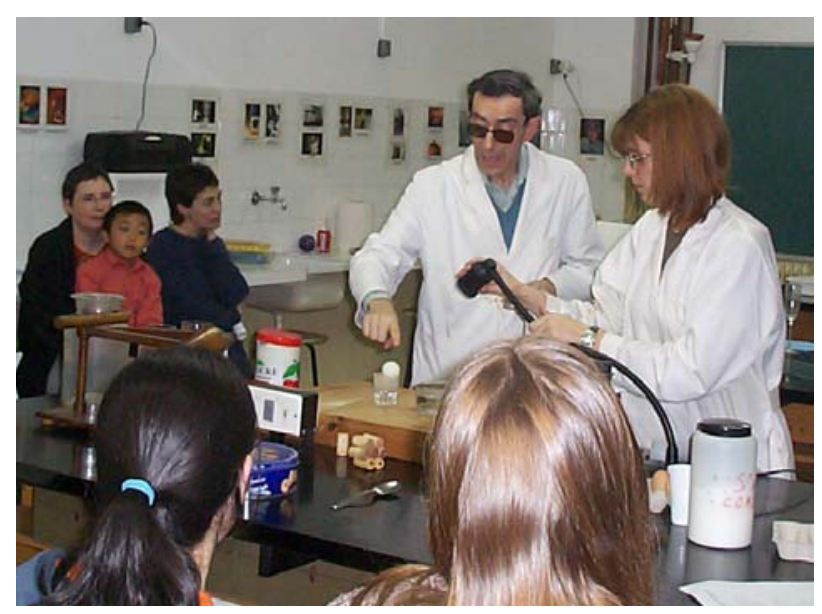

A partir de les 21'30 comença l'activitat pròpiament dita. La persona que condueix l'activitat pot realitzar una explicació teòrica de fins a 30 minuts. Al conductor d'un vespre la condició que se li posa és no fer explicacions teòriques de més de mitja hora. A les 22'00 puntualment es passa al laboratori de física o de química i es realitza l'activitat experimental. Aquesta última pot ser de dues maneres diferents. La primera és que el professor fa experiències espectaculars i els participants només observen i surten com a voluntaris. L'altra opció és fer una mena de taller on els participants són els autèntics protagonistes de l'activitat.

Si tot va bé i no s'allarga, el vespre s'acaba puntualment a les 23'00.

\section{En resum...}

Després de vuit anys estem molt contents d'aquesta activitat. Ens ha permès conèixer persones molt diverses, compartir experiències amb altres docents i continuar veient ex-alumnes que potser no els hauríem tornar a veure més. 